\title{
Transition Metal-Catalyzed and -Promoted Reactions via Carbene and Vinylidene Complexes Generated from Alkynes ${ }^{\dagger}$
}

\author{
Kouichi Ohe \\ Department of Energy and Hydrocarbon Chemisty, Graduate School of Engineering, Kyoto University, Kyoto 615-8510, Japan \\ E-mail: ohe@scl.kpoto-itac;ip \\ Received Angust 8, 2007
}

\begin{abstract}
The transition metal-induced in sifu generation of carbene complexes from alkynes having a carbonyl or imino group as a nucleophilic functionality has been investigated. These reactive carbenoid species are generated with high atom efficiency through a 6-endo-dig cyclization mode based on the electrocyclization of vinylidene complexes or a 5-exo-dig cyclization mode in $\pi$-alkyne complexes, and have been found to serve as versatile intermediates in catalytic carbene transfer reactions. Highlighted and reviewed in this account are the generation and preparation of pyranylidene, furylcarbene, pyrrolylcarbene, and vinylcarbene complexes and their application to [3,3] sigmatropic rearrangement of acylcyclopropylvinylidenes, catalytic cyclopropanation reactions. $[2,3]$ sigmatropic rearrangement or condensation reactions via ylides, ring-opening and substitution reactions with heteroaromatic compounds, and catalytic isomerization of oligoynes.
\end{abstract}

Key Words : Transition metals, Alkyne activation, Vinylidene complexes, Carbene complexes, Catalytic reactions

\section{Introduction}

Transition metal-catalyzed and -promoted reactions involving carbene intermediates are powerful and useful methods for constructing important substructures of targeted molecules, and therefore they have been extensively studied for the past couple of decades.' The in situ generation of metal carbene species is applicable to a wide range of carbene transfer reactions and has attracted recent attention in organic synthesis. One of the most common methods for in sith generation of metal carbene species is a decomposition reaction of diazoalkanes by transition metal compounds. $^{\text {la,b }}$ The diazoalkane method is quite useful, but formidable because of its explosive hazard and a number of unfavorable side reactions. In this context, safe and sure altematives for the diazoalkane method have been eagerly sought. The activation of alkynes with transition metal compounds has recently emerged as a new methodology to ensure the in sim generation of the metal carbene species. ${ }^{23}$ Vinylcarbene intermediates in enyne metathesis, ${ }^{4}$ cyclopropylcarbene species in the cycloisomerization of enynes, ${ }^{5,6}$ dialkylidene metal species via reductive cyclization of $\omega$ diynes, ${ }^{7}$ and vinylcarbenes and/or metal-containing benzopyryliums from alkynes bearing nucleophilic functional groups $^{8.9}$ have exemplified the rapidly emerging class of carbene species.

\footnotetext{
${ }^{\dagger}$ This paper is dedicated to Professor Sang Chul Shim on the occasion
} of his honorable retirement.

Kouichi Ohe was born in Kyoto in 1960 . He received his B. Eng. from Kyoto University in 1984 under the direction of Professor Masaya Okano and received his $\mathrm{Ph} . \mathrm{D}$. from Kyoto University in 1989 under the direction of Professors Sakae Uemura and Nobuyuki Sugita. He became an assistant professor of Professor Murai's group
Recently, we have sought to develop new transition metalcatalyzed or -promoted reaction using carbonyl-ene-ynes $\mathbf{A}$ as precursors of metal carbene species, and found new types of reactions involving 5-exo-dig cyclization based on the coarctate reaction of $\pi$-alkyne complexes, as well as 6-endodig cyclization based on the electrocyclization of vinylidene complex intermediates, leading to six-membered 2-pyranylidene complexes $\mathbf{B}$ and five-membered (2-furyl)carbene complexes $\mathbf{C}$ (Scheme 1). We have also demonstrated that cyclization in the 5-exo-dig manner could be applied to similar structures, propargyl esters $\mathbf{D}$, to yield vinylcarbene complexes $\mathbf{E}$ (Scheme 2). ${ }^{2}$

All of these reactions are promoted by a wide range of

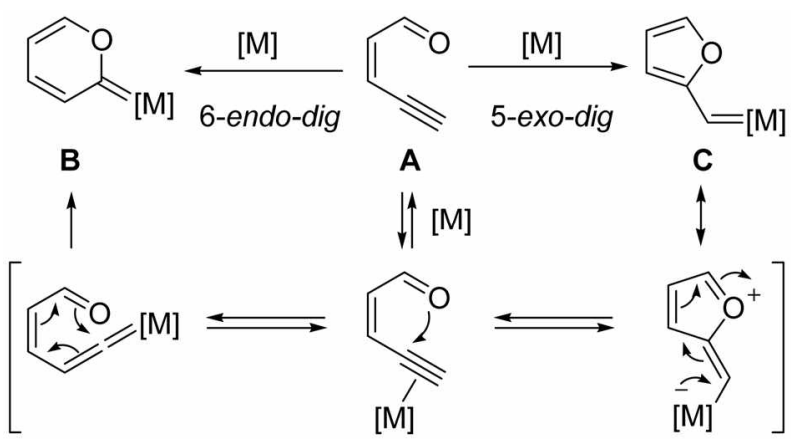

Scheme 1

at Osaka University in 1989. He then moved back to Kyoto University as an associate professor in 1994. In 2003, he was promoted to Professor of Chemistry. He worked for Professor K. C. Nicolaou as a postdoctoral research fellow for one year $(1992-1993)$ at the Scripps Research Institute. He received The Chemical Society of Award of Japan for Distinguished Young Chemists in 1995. His research interest centers on organic synthesis using transition metalcatalysis. 


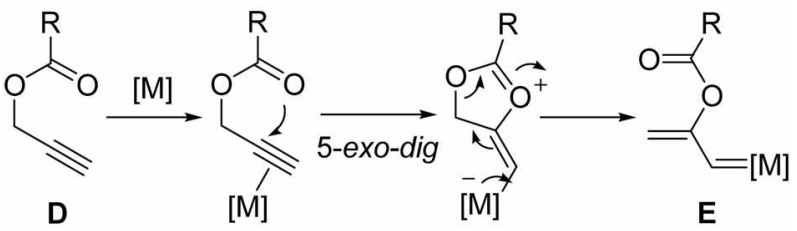

Scheme 2

transition metal compounds. ${ }^{2}$ Moreover, these reactions are highly atom-economical and widely applicable to catalytic carbene transfer reactions. This account describes our recent progress in this field, particularly focusing attention not only on the in situ generation of metal carbene species from alkynes possessing a carbonyl, a thiocarbonyl, or an imine, but also on the application to catalytic carbene transfer reactions.

\section{Cyclic Carbene Complexes from Conjugated Alkynes}

In 1996, we developed rhodium-catalyzed cycloaromatization of conjugated acyclic enediynes involving vinylidenemetal and radical intermediates (Scheme 3 ). ${ }^{100}$ Our continuing investigation has led to new findings involving the interesting 6-endo-dig cyclization based on the concept of electrocyclization of vinylidene complexes. When we carried out the reaction of the carbonyl-ene-yne compound 1a with a tungsten pentacarbonyl THF complex, the cyclic carbene complex, (2-pyranylidene)tungsten complex $\mathbf{2 a}$, was isolated in $63 \%$ yield (Scheme 4 ). ${ }^{11}$ The reaction of the amide derivative $\mathbf{1 b}$ also yielded the corresponding 2pyranylidene complex $\mathbf{2 b}$. With chromium complexes, the

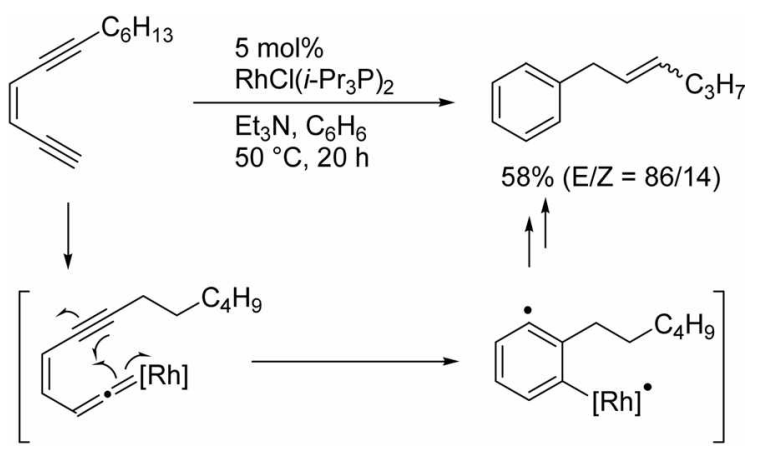

Scheme 3

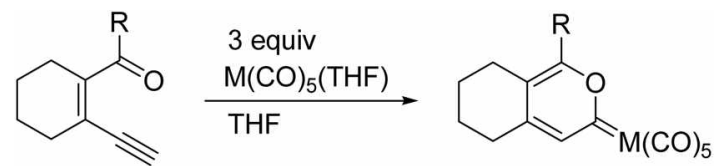

1a $(R=O M e) \quad 2 a(63 \%, M=W$, reflux $0.5 \mathrm{~h})$

1b $\left(R=N E t_{2}\right) \quad$ 2b $(68 \%, M=W$, reflux, $0.5 \mathrm{~h})$

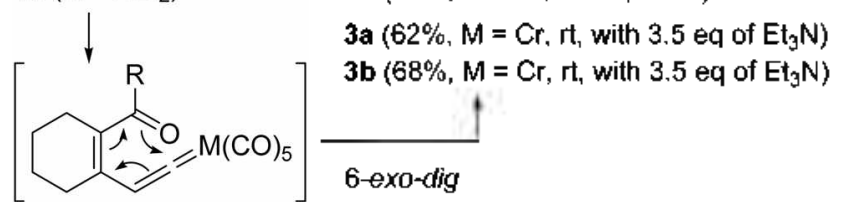

Scheme 4
Table 1. Preparation of 2-Pyranylidene Complexes
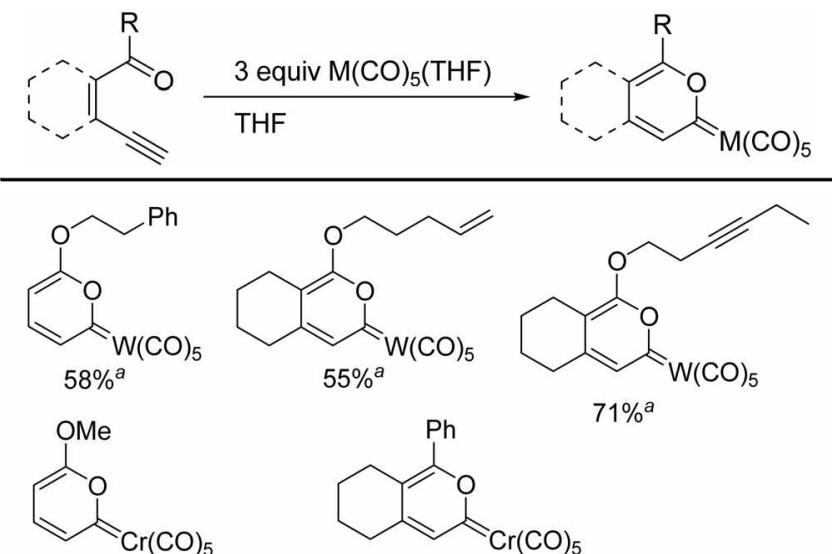

$69 \%^{b}$

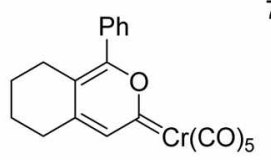

$71 \%^{a}$

${ }^{4}$ At reflux temperature for $0.5 \mathrm{~h}$. "With 3.5 equiv of $\mathrm{E} \mathrm{t}_{3} \mathrm{~N}$ at room temperature for $2 \mathrm{~h}$. With 1.2 equiv $\mathrm{E}_{3} \mathrm{~N}$ at room temperalure for $0.5 \mathrm{~h}$.

addition of triethylamine $\left(\mathrm{Et}_{3} \mathrm{~N}\right)$, which is well known to promote the isomerization from $\omega$-alkyne complexes to vinylidene complexes, ${ }^{10.11}$ is essential to produce the corresponding products $3 \mathbf{a}$ and $\mathbf{3 b} .^{12 a}$ Representative results of the synthesis of various 2-pyranylidene complexes are summarized in Table 1. Irrespective of the cyclic or acyclic carbonylene-yne compound used, 2-pyranylidene complexes were obtained in good yields. Alkenyl and alkynyl moieties were tolerated under the reaction conditions, leading to 2pyranylidene complexes. However, in the reaction of a ketoene-yne compound the 2-pyranylidene complex was obtained in only $8 \%$ yield together with many unidentified products. Surprisingly, reactions of keto-ene-yne compounds without $\mathrm{Et}_{3} \mathrm{~N}$ yielded deep-blue (2-fury])carbene complexes, which were produced via 5-exo-dig cyclization (vide (nfra). ${ }^{12}$ Since we found that the six-membered Fischer-type carbene complexes could be generated by electrocyclization (pericyclic reaction) of vinylidene intermediates, we extended the concept for cyclopropane analogues.

As shown in Scheme 5, [3,3]sigmatropy of an acylcyclopropylvinylidene intermediate from cis-1-acyl-2-ethynylcyclopropane 4 was envisioned to produce a seven-membered Fischer-type carbene complex 5 . However, in the reaction of $4 \mathbf{a}$, phenol $6 \mathbf{a}$ as an unanticipated isomerized product was isolated in $69 \%$ yield under reaction conditions identical to those used for the synthesis of 2-pyranylidene-chromium complexes (eq. 1). ${ }^{13}$ A tungsten complex, W(CO) $)_{5}(\mathrm{THF})$ showed similar reactivity to give $6 \mathrm{a}$ in $72 \%$ yield, while $\mathrm{Mo}(\mathrm{CO})_{5}(\mathrm{THF})$ gave $6 \mathrm{a}$ in low yield. The addition of $\mathrm{Et}_{3} \mathrm{~N}$ was essential for this isomerization, irrespective of the group

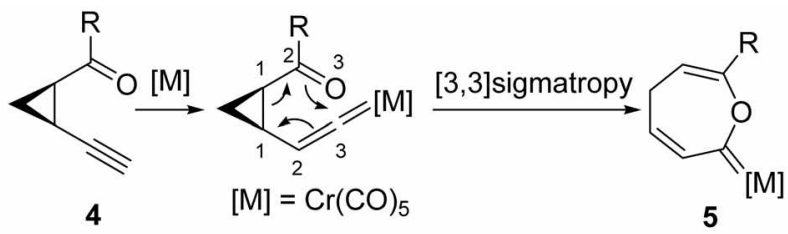

Scheme 5 


$$
\begin{array}{lll}
\text { 3 equiv } M(\mathrm{CO})_{5}(\mathrm{THF}) \\
\mathrm{THF}, \mathrm{Et}_{3} \mathrm{~N}, \mathrm{rt}, 24 \mathrm{~h}
\end{array}
$$

6 metal carbonyls employed. Ester $4 b$ and amide $4 c$ gave no isomerized products, and both substrates were recovered intact. The lack of reactivity of ester and amide derivatives is in sharp contrast with 2-pyranylidene-complex formation (vide supra). Although this interesting reactivity has not been precisely accounted for, the proximity of the carbony] oxygen to the $\alpha$-carbon of a vinylidene moiety and the stability of intermediates probably affect the isomerization reaction.

Considering that no carbene complex was isolated, the isomerization of 4 could be expected to proceed in the presence of catalytic amounts of group 6 metal carbonyls. As expected, the use of $5 \mathrm{~mol} \% \mathrm{Cr}(\mathrm{CO})$ ( THF) is sufficient to induce the catalytic valence isomerization to give the corresponding product quantitatively (Table 2). Reactions of primary and secondary alkyl ketones gave phenols in nearly quantitative yields, while the reactivity of tert-butyl ketone was low because of its bulkiness. When the reactions of $p$ substituted phenyl ketones were examined, electron-withdrawing substituents on a phenyl group, e.g., $\mathrm{CF}_{3}$, decelerated the reaction. These results suggest that the nucleophilicity of the carbonyl oxygen towards the $\alpha$-carbon of a vinylidene moiety plays a critical role in this reaction. Heterocyclic substituents such as the 2-furyl and 2-thienyl groups were tolerated in the reactions, but a 2-pyridyl substituent slightly retarded the isomerization, probably due

Table 2. Catalytic Valenec Isonerization of 4 with $\mathrm{Cr}(\mathrm{CO})_{5}(\mathrm{THF})^{\mathrm{t}}$

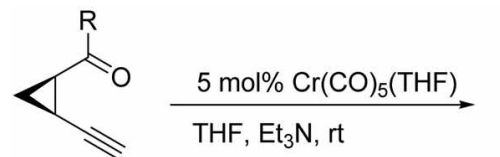

4

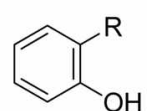

5

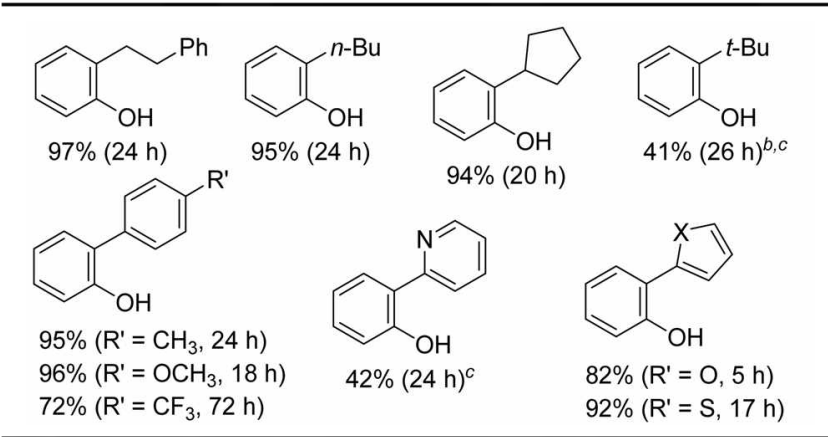

'Reactions were carried oul at room temperalure with 4, EtoN (3 equiv) in the presence of $\mathrm{M}(\mathrm{CO})_{5}(\mathrm{TIT})$ prepared from the irradiation of a solution of $\mathrm{M}(\mathrm{CO})_{6}(5 \mathrm{~mol} \%)$ in TIT. "Catalyst ( $30 \mathrm{~mol} \%$ ). At reflux temperature.<smiles>[R]C1=CC=CC([R])OC1=[W]</smiles><smiles>[R]c1cccc(O)c1O</smiles>

Scheme 6

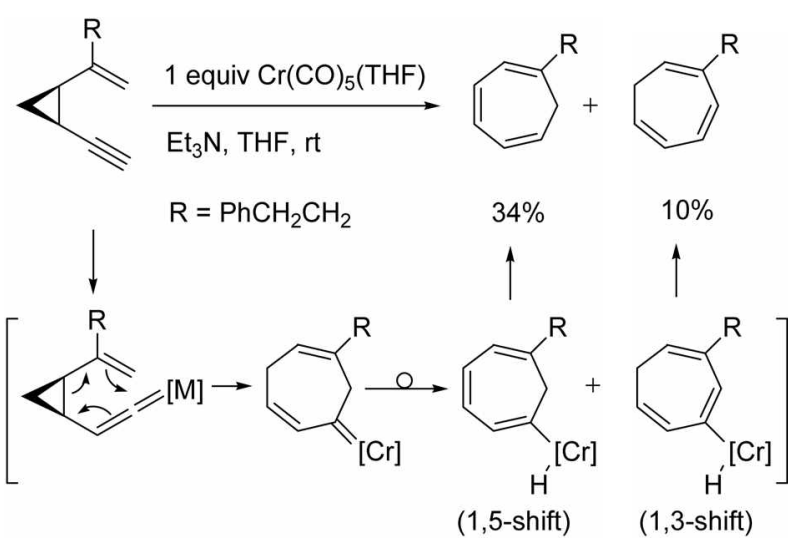

Scheme 7

to the stronger coordination of a nitrogen atom to group 6 metals.

A plausible mechanism for this isomerization can be explained by assuming a multistep pathway as shown in Scheme 6. The [3,3]sigmatropic reaction of an acylcyclopropylvinylidene complex produces [-oxa-3,6-cycloheptadien-2-ylidene complex 5. A [1,5]-H shift and/or [1,3]-H shift from $\mathrm{CH}_{2}$ in the seven-membered ring of $\mathbf{5}$, followed by reductive elimination of $\mathrm{M}(\mathrm{CO})_{5}(\mathrm{M}=\mathrm{Cr}, \mathrm{Mo}, \mathrm{W})$ results in a formation of an oxepin as a primary product. The oxepin, which is in equilibrium with the arene oxide, is converted into a phenol with the assistance of $\mathrm{M}(\mathrm{CO})_{5}$ as a Lewis acid under the reaction conditions. The formation of a mixture of cycloheptatrienes from cis-1-ethynyl-2-vinylcyclopropane as a carbon analogue of $4 \mathbf{a}$ under the isomerization conditions strongly supports the intermediary sevenmembered oxacarbene complexes 5 (Scheme 7). ${ }^{13}$

\section{(2-Furyl)carbene Complexes from Conjugated Alkynes}

In the course of the investigation of 2-pyranylidene complexes we found a new carbene complex formation from carbonyl-ene-ynes 7a through 5-exo-dig cyclization, leading to (2-furyl)carbene complexes $\mathbf{8 a}$ and $\mathbf{8 b}$ (Scheme 8). ${ }^{12 \mathbf{a}}$ 


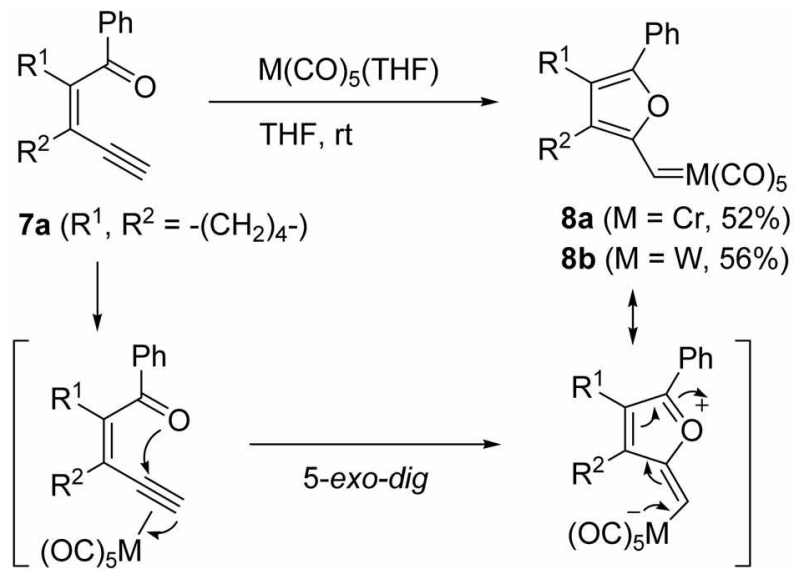

Scheme 8

These complexes $\mathbf{8} \mathbf{a}$ and $\mathbf{8 b}$ are less stable than 2-pyranylidene complexes and they gradually decompose to give dimerized products, 1,2-difurylethene derivatives, in high yield after 4 days. ${ }^{14 \mathrm{k}}$ We further examined catalytic (2furyl)carbene transfer reactions using keto-ene-yne compounds as carbene precursors in the presence of carbene acceptors, such as alkenes and allyl sulfides.

The reaction of carbonyl-ene-yne $7 \mathbf{a}$ with styrene in the presence of a catalytic amount of $\operatorname{Cr}(\mathrm{CO}) \leqslant(\mathrm{THF})$ afforded (2-furyl)cyclopropane 9a in $85 \%$ yield (eq. 2). ${ }^{1+}$ Interest-<smiles>C#CC1=C(C(=O)c2ccccc2)CCCC1</smiles>

ingly, complexes of late transition metals, such as $\mathrm{Ru}, \mathrm{Rh}, \mathrm{Ir}$, $\mathrm{Pd}$, and $\mathrm{Pt}$, also catalyze cyclopropanation involving (2furyl)carbene intermediates (Table 3). The complex $\left[\mathrm{Rh}(\mathrm{OAc})_{2}\right]_{2}$ showed the highest catalytic activity in the cyclopropanation reaction. The selected results from cyclopropanation reactions of several alkenes using $\left[\mathrm{Rh}(\mathrm{OAc})_{2}\right]_{2}$ as a catalyst are shown in Table 4. Electron-rich alkenes such as tert-butyl vinyl ether and ketene diethyl acetal served as good acceptors

Table 3. Catalytic Cyclopropanation of $7 \mathrm{a}^{\mathrm{at}}$

\begin{tabular}{|c|c|c|}
\hline Cat. & Time (h) & Yield of $9 \mathrm{a}$ (cis:trans) \\
\hline $\mathrm{W}(\mathrm{CO}) \leqslant(\mathrm{THF})$ & 2 & $54 \%(70: 30)$ \\
\hline$[\operatorname{RuCl}(p \text {-cymene })]^{b}$ & 2 & $85 \%(33: 67)$ \\
\hline$\left[\mathrm{RuCl}_{2}\left(\mathrm{CO}_{3}\right]_{2}{ }^{b}\right.$ & 24 & $42 \%(12: 88)$ \\
\hline$\left[\operatorname{Rh}(\mathrm{OAc})_{2}\right]_{2}^{b}$ & 1 & $93 \%(8: 92)$ \\
\hline$[\operatorname{IrCl}(\operatorname{cod})]]^{b}$ & 2 & $92 \%(57: 43)$ \\
\hline $\mathrm{PdCl}_{2}$ & 2 & $79 \%(21: 79)$ \\
\hline $\mathrm{PtCl}_{2}$ & 1 & $81 \%(23: 77)$ \\
\hline
\end{tabular}

${ }^{\circ}$ Reactions were carried out at rom temperature with $7 \mathrm{a}$, styrene $(20$ equiv), and a catalyst (5 mol\%) in THF unless otherwise noted. "Styrene ( 2 equiv) with a calalyst $(2.5 \mathrm{~mol} \%)$.
Table 4. Rhodiuın-Catalyzed Cyclopropanation of $7^{\text {it }}$
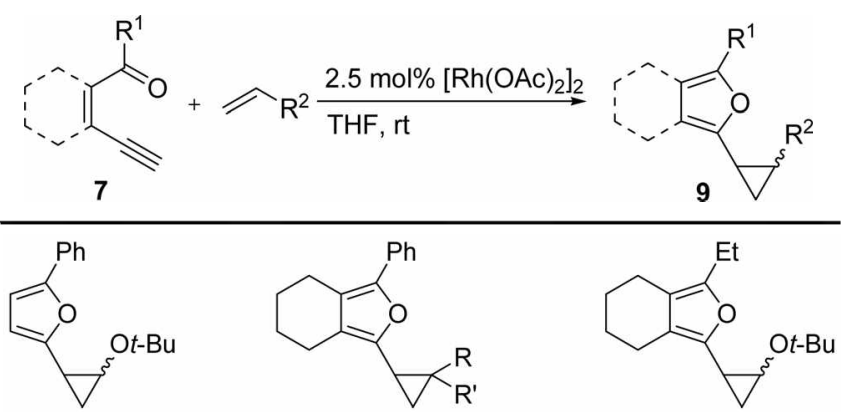

$99 \%(85: 15)^{b}$

$99 \%\left(90: 10,{ }^{b} \mathrm{R}=\mathrm{O} t-\mathrm{Bu}, \mathrm{R}^{\prime}=\mathrm{H}\right)$ $99 \%\left(R, R^{\prime}=O E t\right)$

$80 \%(91: 9)^{b, c}$

Reactions were carried out at room temperature with 7 , alkene $(2$ equiv), and $\left[\mathrm{Rh}(\mathrm{OAc})_{2}\right]_{2}(2.5 \mathrm{~mol} \%)$ in THF for $\mathrm{l} \mathrm{h}$ unless otherwise noted. ${ }^{h}$ The ratio of cis:trans. "In dichloromethane.

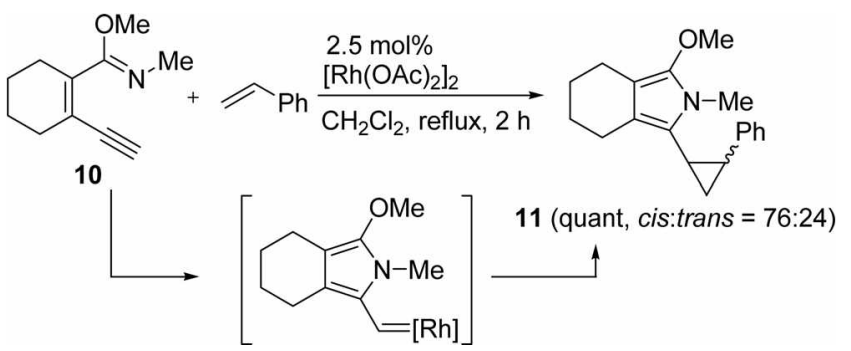

Scheme 9

of carbene intermediates to give the cyclopropanated products in excellent yields. The complex $\left[\mathrm{Rh}(\mathrm{OAc})_{2}\right]_{2}$ can act as an effective catalyst in the cyclopropanation with an alkyl ketone, which led to lower yield of cyclopropanated product in other transition metal catalysis.

We next attempted to study the reactivity of the nitrogen analogue of 7 . As shown in Scheme 9, imino ether 10 reacted with styrene to give (2-pyrroly])cyclopropane 11 in quantitative yield. ${ }^{15}$ The pyrrolylcyclopropanes can be easily converted to 2-pyrrolinones in good yields under mild hydrolysis conditions. ${ }^{15}$

To extend the scope of the in situ generation of metal carbene in organic synthesis, we examined the reaction with other carbene acceptors, such as allyl sulfides or phosphines,

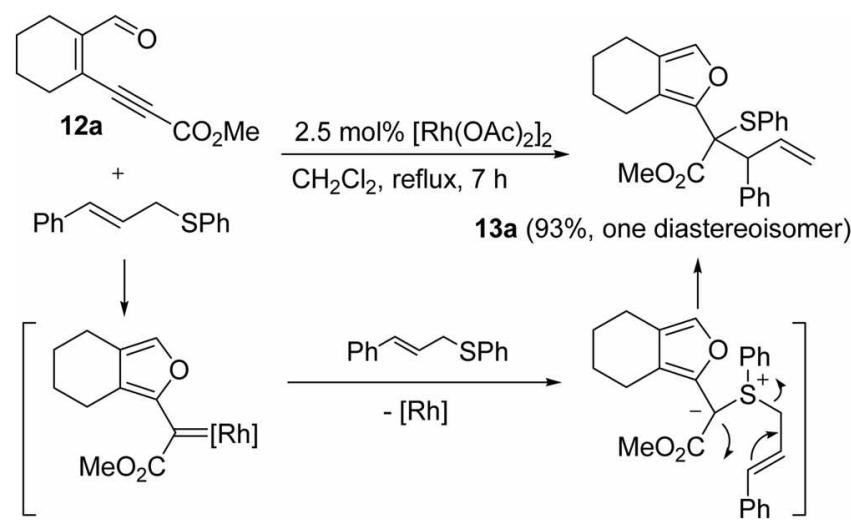

Scheme 10 


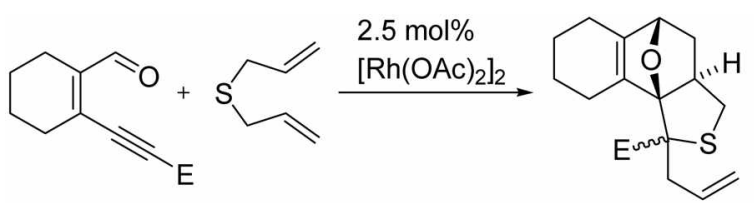

$12 \mathrm{a}\left(\mathrm{E}=\mathrm{CO}_{2} \mathrm{Me}\right)$ $12 b(E=B z)$

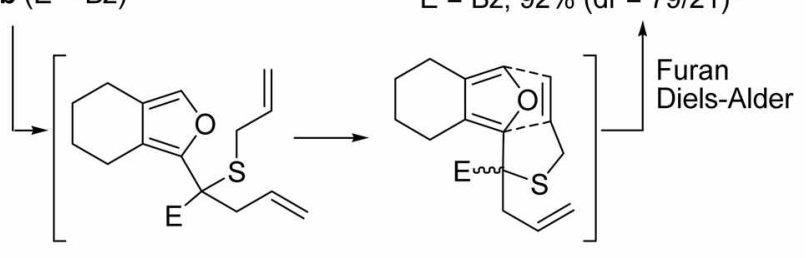

Reaction key: a: $\mathrm{CH}_{2} \mathrm{CH}_{2}$, reflux, $120 \mathrm{~h}$; b: DCE, $80^{\circ} \mathrm{C}, 72 \mathrm{~h}$.

Scheme 11
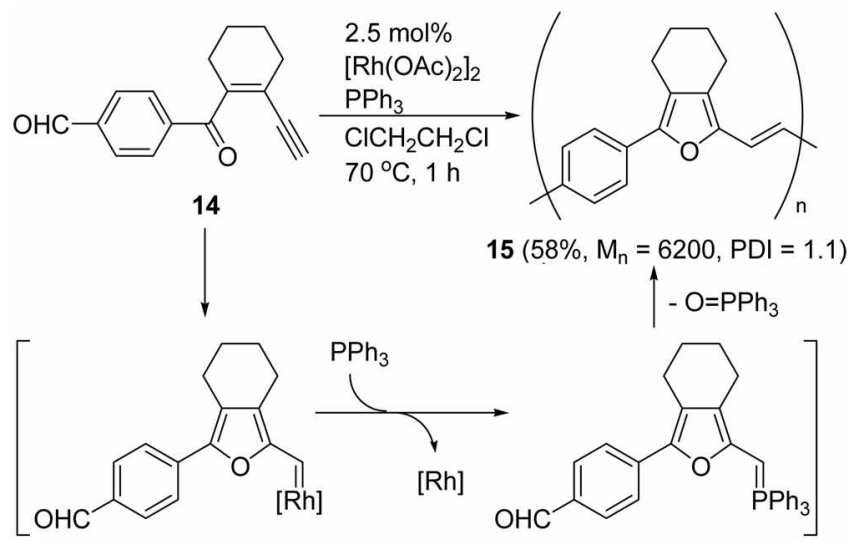

Scheme 12

which are well known as effective carbene acceptors in catalytic carbene transfer reactions using diazoalkanes. We undertook the rhodjum(II)-catalyzed Doyle-Kirmse type reaction using carbonyl-ene-yne compound 12a as an alternative source of diazoalkanes (Scheme 10 ). ${ }^{16}$ The resulting sulfur ylide produced by 2 -furylcarbene transfer, efficiently undergoes $[2,3]$ sigmatropic rearrangement to give furancontaining sulfide 13a. Using a diallyl sulfide instead of the monoallyl sulfide, a reaction cascade of $[2,3]$ sigmatropy followed by an intramolecular furan Diels-Alder reaction allows the one-pot synthesis of polycyclic heterocycles (Scheme 11). ${ }^{16}$

In a similar manner to sulfur ylide formation, carbene transfer to phosphines, which sequentially undergo a Wittigtype condensation with formyl groups, could produce phosphorus ylides. The catalytic reaction of carbonyl-ene-yne monomer 14 having a formyl group could be applied to the polycondensation reaction leading to $\pi$-conjugated polymers 15 with low polydispersity (PDI = 1.1) (Scheme 12). ${ }^{17 a}$ The low polydispersity is probably due not only to the low concentration of ylides but also to the selective reaction between the resulting oligomeric ylides and a monomer substrate 14 (carbonyl-ene-yne) involving a highly electrophilic formyl group para to a ketone moiety.

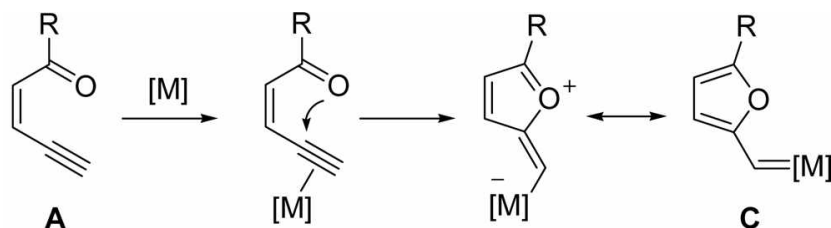

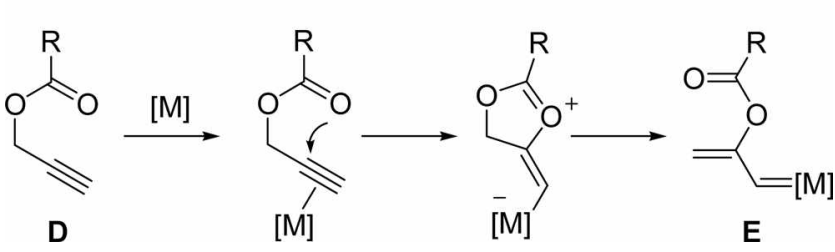

Scheme 13

\section{Vinylcarbene Complexes from Propargyl Esters and Related Compounds}

We have described that (2-furyl)carbene complexes $\mathbf{C}$ could be generated from carbonyl-ene-yne compounds $\mathbf{A}$ with a wide range of transition metal complexes and could be applied to catalytic carbene transfer reactions (vide supra). This protocol was envisioned to extend to the system of propargyl esters in almost similar manner. We successfully explored a novel method for generation of vinylcarbenoid intermediate $\mathbf{E}$ from propargyl esters $\mathbf{D}$ (Scheme 13).

In 1984, Rautenstauch reported that a palladium catalyst undergoes 1,2-migration of an acetate group in 1-ethnyl-2propenyl acetates to give cyclopentenones. ${ }^{18 a b}$ However, facile isomerization of propargyl esters into allenyl esters catalyzed by transition metal compounds has precluded the further progress of this unique and potentially useful reaction. ${ }^{19,20}$ In 2002 , it was reported that intermediary vinylcarbenoids were effectively trapped intramolecularly

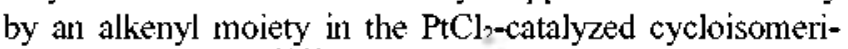
zation of dienynes. ${ }^{2122}$ Our continuing investigation of the generation of carbene species by transition metal-promoted alkyne activation led us to develop efficient catalytic carbene transfer reactions, such as cyclopropanation, ${ }^{23}$ annulation, ${ }^{23-25}$ ring-opening and substitution reactions, ${ }^{26,27}$ and other miscellaneous reactions ${ }^{2 \gamma}$ using propargyl esters and related compounds as precursors of vinylcarbene complexes.

Cyclopropanation of styrene with 2-methyl-3-butyn-2-yl acetate (16a) in the presence of transition metal catalysts that had been effective for catalytic cyclopropanation via (2furyl)carbene complexes was examined (eq. 3). Representa-

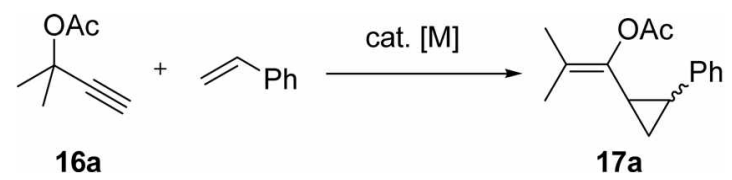

tive results of catalyst screening and optimization are given in Table 5. The reaction of $16 \mathrm{a}$ with styrene in the presence of a catalytic amount of $\mathrm{PtCl}_{2}$ in toluene at $60^{\circ} \mathrm{C}$ for $\mathrm{I} \mathrm{h}$ 
Table 5. Transition Metal-Catalyzed Cyclopropanation of 16a with Styrene"

\begin{tabular}{|c|c|c|c|c|c|}
\hline $16 a$ & $\mathrm{Ph} \frac{\text { cat. }}{\text { tolu }}$ & $60^{\circ} \mathrm{C}$ & $17 a^{2}$ & & $={ }^{O A}$ \\
\hline Entry & [M] & Time & $17 \mathrm{a}(\%)$ & cisitrans & $18(\%)$ \\
\hline 1 & $\mathrm{PtCl}_{2}$ & $1 \mathrm{~h}$ & 93 & $78: 22$ & 7 \\
\hline $2^{5}$ & $\mathrm{PtCl}_{2}$ & $10 \mathrm{~h}$ & 74 & $80: 20$ & 23 \\
\hline 3 & {$\left[\mathrm{RuCl}_{2}(\mathrm{CO})_{3}\right]_{2}$} & $18 \mathrm{~h}$ & 86 & $80: 20$ & 5 \\
\hline $4^{h}$ & {$\left[\mathrm{RuCl}_{2}(\mathrm{CO})_{3}\right]_{2}$} & $18 \mathrm{~h}$ & 99 & $87: 13$ & 0 \\
\hline 5 & {$\left[\mathrm{Rh}\left(\mathrm{OCOCF}_{3}\right)_{2}\right]_{2}$} & $30 \mathrm{~min}$ & trace & - & 99 \\
\hline 6 & $\mathrm{AuCl}_{3}$ & $10 \mathrm{~min}$ & 63 & $79: 21$ & 26 \\
\hline
\end{tabular}

Reaction conditions: $16 \mathrm{a}$, styrene ( 5 equiv), catalyst ( $2.5 \mathrm{~mol} \%$ ), toluene, $60^{\circ} \mathrm{C}$. ${ }^{\circ}$ Tn DCE $(1,2$-dichloroethane $)$ at $50^{\circ} \mathrm{C}$. At $25^{\circ} \mathrm{C}$.

afforded the cyclopropanated product $17 \mathrm{a}$ in $93 \%$ yield, along with $7 \%$ of allenyl acetate 18 as the isomerization product of 16a. On the other hand, the use of 1,2-dichloroethane (DCE) as solvent in platinum catalysis decreased both yield and selectivity. The complex, $\left[\mathrm{RuCl}_{3}(\mathrm{CO})_{3}\right]_{2}$ was found to be a most effective catalyst with excellent yield in the cyclopropanation reaction with $16 \mathrm{a}$ in DCE at $50^{\circ} \mathrm{C}$. In contrast, $\left[\mathrm{Rh}\left(\mathrm{OCOCF}_{3}\right)_{2}\right]_{2}$ catalyzed isomerization of $\mathbf{1 6 a}$ into allenyl acetate 18 with high selectivity. $\mathrm{AuCl}_{3}$ also catalyzed the cyclopropanation, but 18 was produced to some extent. 230.5

Under optimized conditions $\left(2.5 \mathrm{~mol} \%\left[\mathrm{RuCl}(\mathrm{CO})_{3}\right]_{2}\right.$, DCE, $50^{\circ} \mathrm{C}$ ), the reactions of several types of propargyl esters with alkenes were carried out (Table 6). The reactions of propargyl benzoate and esters of an ethynylcycloalkanol with styrene gave the cyclopropanated products in excellent yields. The reaction with secondary propargyl acetate substituted with phenyl proceeded smoothly to give cis-alkenylcyclopropane in $77 \%$ yield. However, a secondary propargy] ester having an alkyl group at the propargylic position was less reactive than those having an aryl group, affording a cyclopropane in low yield $(<30 \%)$. Primary propargyl esters and propargyl esters having a substituent on an alkyne

Table 6. Ru-Catalyzed Cyclopropanation

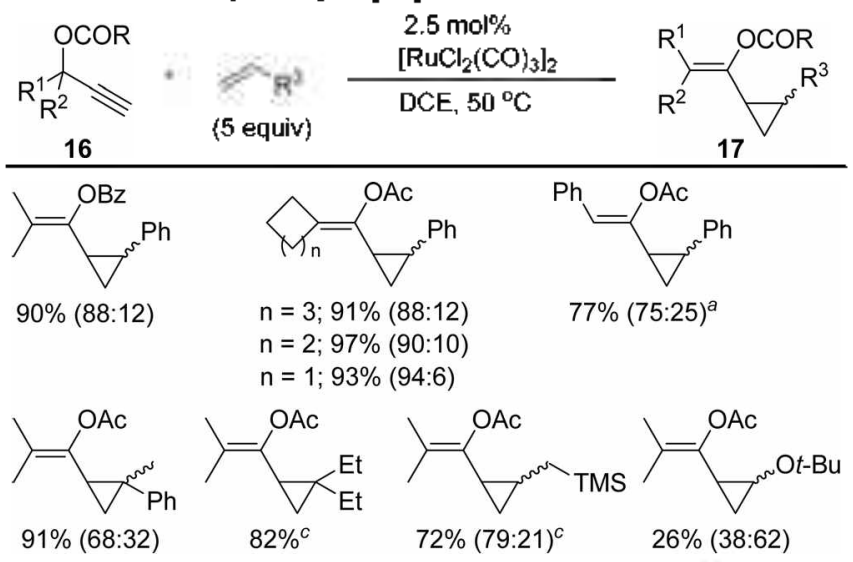

The ratio of cis trums in parentheses. "In toluene at $60^{\circ} \mathrm{C}$. "Alkene $(20$ equiv).

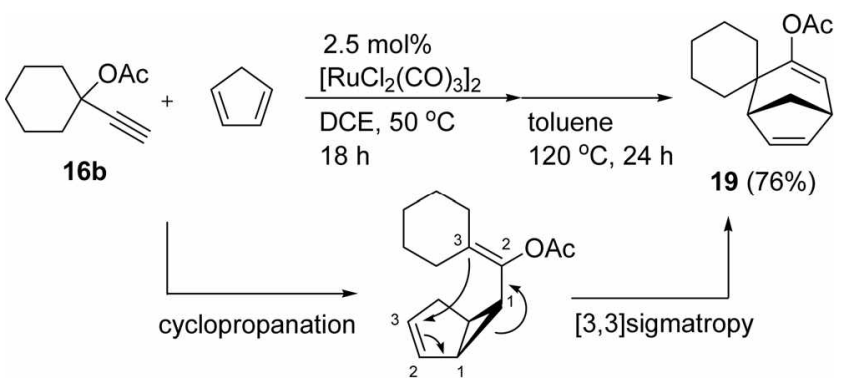

Scheme 14

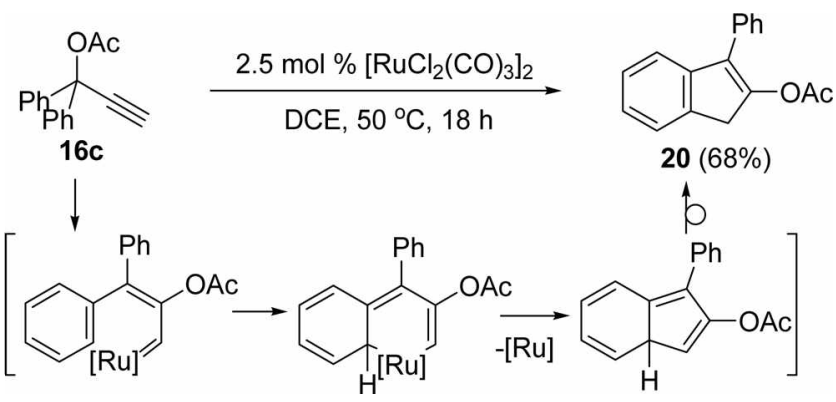

Scheme 15

terminus were much less reactive and cyclopropane formation scarcely occurred. The reaction of $\alpha$-methylstyrene with $16 \mathrm{a}$ proceeded smoothly to give cyclopropane in good yield. 2Ethylbut-I-ene and allyltrimethylsilane slowly reacted with $16 \mathrm{a}$ to give the corresponding products in good yields, although the use of excess alkenes was required. On the other hand, cyclopropanation of tert-butyl vinyl ether with 16a resulted in lower yield. Electron-deficient alkenes such as methyl acrylate did not work at all in the present cyclopropanation.

Furthermore, this catalytic system could be applied to the reaction with conjugated dienes as carbene acceptors. ${ }^{23 \mathrm{k}}$ In this case, a seven-membered ring could be fonmed from cyclopropanation followed by $[3,3]$ sigmatropic rearrangement of vic-divinylcyclopropane intermediate. The rutheniumcatalyzed reactions with cyclopentadiene produced a bicyclo[3.2.1]octadiene skeleton (Scheme 14). Efficient [3,3]sigmatropic isomerization of initially formed swn-divinylcyclopropane led to the rearranged product 19 by heating the solution at $120^{\circ} \mathrm{C}$ after ruthenium-catalyzed cyclopropanation. The present vinylcarbene transfer reaction is chemically equivalent to the reaction using a combination of $\alpha$-diazoketone and transition metal compounds.

The ruthenium-catalyzed reaction of $16 \mathrm{c}$ undergoes intramolecular pentannulation to give 2-acetoxy-3-phenyl-2indene 20 (Scheme 15). ${ }^{23 \mathrm{~b}}$ The $6 \pi$-electrocyclization of a ruthenatriene intermediate is proposed as the most likely mechanism for the indene formation. ${ }^{2+}$ This is also considered as a formal insertion of the carbene center into a $\mathrm{C}-\mathrm{H}$ bond of a phenyl ring. Most recently, we have found that the similar pentannulation of 1-aryl-2-propynyl esters is catalyzed by $\mathrm{PtCl}_{2}$ efficiently. ${ }^{2+25}$

The diazoalkane-free in situ generation of metal-vinylcarbene intermediates from propargyl esters can be applied 


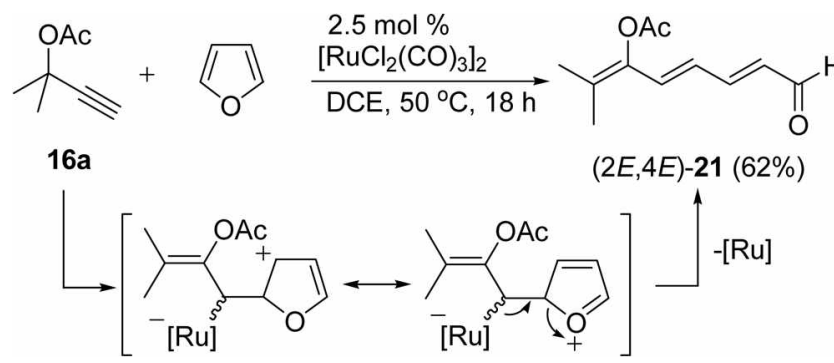

Scheme 16

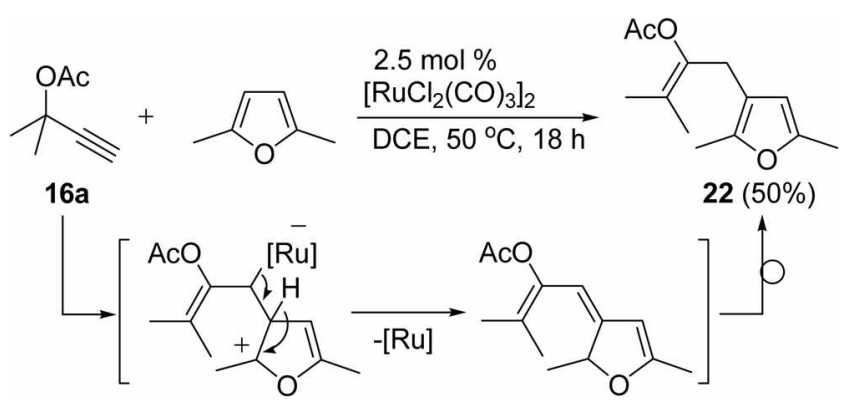

Scheme 17

to ring-opening and substitution reactions of heteroaromatic compounds. ${ }^{26}$ The reaction of 2-methyl-3-butyn-2-yl acetate (16a) with furan in the presence of a catalytic amount of $\left[\mathrm{RuCl}_{2}(\mathrm{CO})_{3}\right]_{2}$ affords triene $(2 E, 4 E)-21$ in $62 \%$ yield (Scheme 16). Trienes obtained are in general a mixture of stereoisomers, which are prone to isomerize to the most thermally stable $(2 E, 4 E)$-isomer. Ruthenium-vinylcarbene formation followed by electrophilic attack to a furan gives a charge-separated intermediate, which undergoes the ringopening of the furan structure to produce the triene. The ruthenium-catalyzed reaction of 16a with 2,5-dimethylfuran gives 3-substituted 2,5-dimethylfuran 22 in $50 \%$ yield instead of ring-opened products (Scheme 17). The chargeseparated intermediate, which is formed by electrophilic attack of a ruthenium-vinylcarbene at the 3-position of 2,5dimethylfuran, probably because of the sterical preference, allows hydride shift exclusively to give 3 -substituted products.

Although 1,1-dialkyl- or 1,1-diary]-2-propynyl esters and 1-aryl-2-propynyl esters can act as vinylcarbene precursors, no vinylcarbene complex formation from I-alkyl-2-propyn$\mathrm{yl}$ and simple propargyl esters was observed. The reaction of

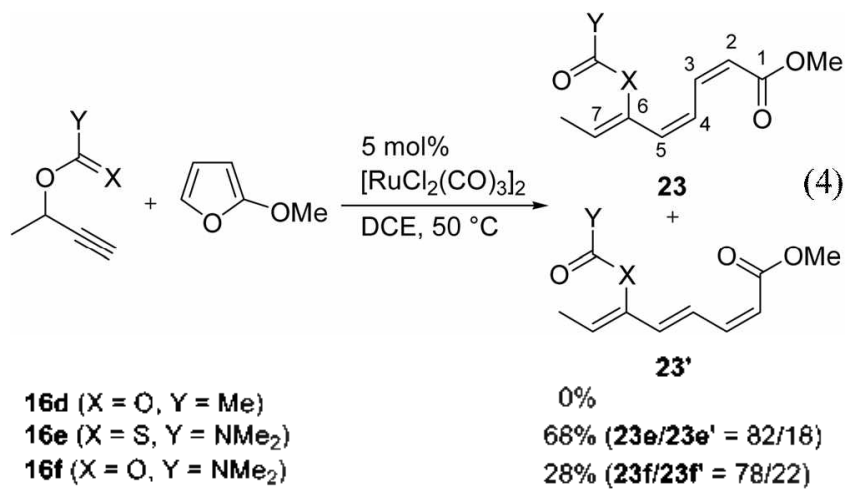

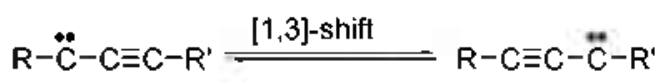

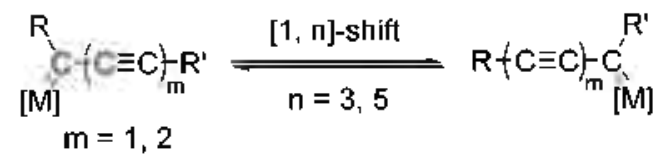

Scheme 18

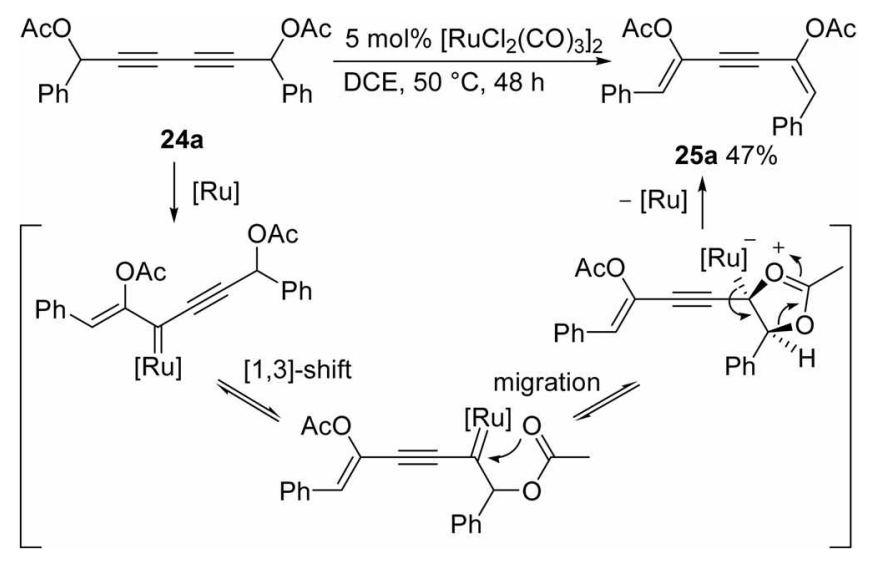

Scheme 19

acetate 16d $(X=O, Y=M e)$ with 2-methoxyfuran did not take place, 16d being recovered intact (eq. 4). We have found that $O$-propargyl thiocarbamate 16e $(X=S, Y=$ $\mathrm{NMe}_{2}$ ) works as vinylcarbene precursors and could be used for transition metal-catalyzed vinylcarbene transfer reactions. ${ }^{27}$ However, the similar reaction of 3-butyn-2-y] $N, N$ dimethylcarbamate $16 \mathrm{f}\left(\mathrm{X}=\mathrm{O}, \mathrm{Y}=\mathrm{NMe}_{2}\right)$ afforded ringopened products in lower yields. These results indicate that the higher nucleophilicity of the sulfur atom and the mesomeric effect of the $N, N$-dimethylamino moiety synergistically promote the efficient generation of a metal-vinylcarbene intermediate. The extended reactivity of propargyl substrates as vinylcarbene precursors might find application in the construction of important substructures of desired molecules.

The $[1,3]$ shift of the carbene center to the remote alkynyl carbon in free alkynyl carbenes (a) ${ }^{29}$ and alkynyl carbene complexes $(b)^{30.31}$ have been recognized as an intriguing dynamic process (Scheme 18). Recently, the in situ generation of carbene complexes from oligoynes has been applied to study the dynamic behavior of an intermediary carbene complex in catalytic reactions. ${ }^{32}$ When we examined the generation of ruthenjum-carbene complexes from conjugated oligoyne systems possessing propargyl acetate moieties as a carbene donor, we found the metallotropic shift in intermediates from oligoynes leading to the catalytic isomerization. 28.33

The reaction of 1,6-diacetoxy-1,6-diphenylhexa-2,4-diyne (24a) bearing the secondary propargyl acetate moiety in DCE in the presence of $\left[\mathrm{RuCl}_{2}(\mathrm{CO})_{3}\right]_{2}$ gave $(\mathrm{I} Z, 5 E)-2,5-$ diacetoxy-1,6-diphenylhexa-1,5-diene-3-yne (25a) as an isomerized product (Scheme 19). ${ }^{28}$ Since we know that the 


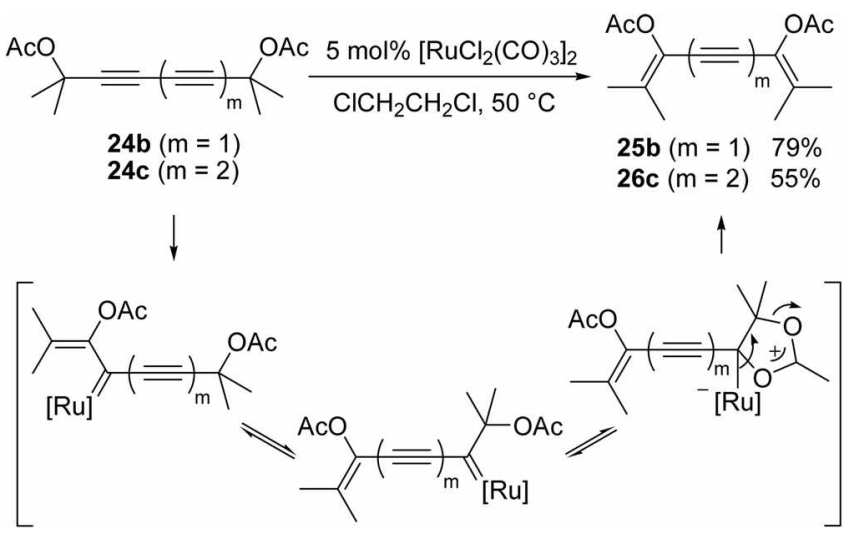

Scheme 20

secondary propargyl acetate gives $Z$-vinylcarbene complex (See Table 6), ${ }^{23 a b}$ the $Z$-stereochemistry of $25 a$ strongly supports the generation of the vinylcarbene complex. We have proposed that the most plausible mechanism involves the generation of a vinylcarbene complex and subsequent $[1,3]$ shift of the carbene center to the remote alkynyl carbon followed by stereoselective migration of vicinal acetate.

Reactions of symmetrical diyne $\mathbf{2 4 b}$ and triyne $\mathbf{2 4 c}$ gave 3,6-diacetoxy-2,7-dimethylocta-2,6-diene-4-yne (25b) and 3,8-diacetoxy-2,9-dimethyldeca-2,8-diene-4,6-diyne (25c) (Scheme 20). ${ }^{28}$ The results suggest the ruthenium-catalyzed isomerization of diynes and triynes by using in situ generation of transition metal-carbene complexes from propargy] esters, followed by $[1, n]-$ metallotropic carbene shift $(n=3$, 5) (carbene walk) of initially generated alkynyl carbene complexes.

\section{Conclusion}

We have developed a new route to carbene complexes, 2pyranylidene, (2-furyl)carbene, (2-pyrrolyl)carbene, and vinylcarbene complexes, from alkynes possessing nucleophilic auxiliaries, and have demonstrated several efficient catalytic reactions involving the in situ generation of such carbene species. The latent nature of alkynes as carbene precursors $(-\mathrm{C}=\mathrm{C}-\leftrightarrow-\overrightarrow{\mathrm{C}}-\overrightarrow{\mathrm{C}}-)$ is brought out by the perturbation of $\pi$-electrons in alkynes coordinated with transition metals. Vinylidene complexes generated in situ from terminal alkynes serve as a $2 \pi$-unit for a 6-endo-dig cyclization mode in electrocyclization and $[3,3]$ sigmatropy to create cyclic oxacarbene complexes. Vinylidene formation is not a prerequisite for producing (2-fury])carbene, (2-pyrroly])carbene, and vinylcarbene complexes, formation of which are driven by 5-exo-dig cyclization with a carbonyl or imino group as nucleophiles to an intemal carbon in $\pi$-alkyne complexes. The present study, based on the in situ generation of carbenoid species from alkynes coordinated with transition metals, provides a variety of efficient carbene transfer reactions with high atom efficiency. We believe that this new accessibility to carbenoid species contributes to the development of organic synthesis as well as organometallic chemistry. Further advances in this area await discovery.
Acknowledgements. The author is grateful to all coworkers, whose names appear in the references, for their invaluable intellectual and experimental contributions to this fascinating research field. He wishes to express his deepest gratitude to Professor Emeritus Sakae Uemura for his encouragement and helpful discussions. The financial support by Grant-in-Aid for Scientific Research on Priority Areas "Synergistic Effects for Creation of Functional Molecules" (Area 459, No. 19027027) and Scientific Research B (No. 19350093) from the Ministry of Education, Culture, Sports, Science, and Technology, Japan, is gratefully acknowledged.

\section{References}

1. (a) Zaragoza Dōrwald. F. Metal Carbenes in Orgamic Sinthesis; Wiley-VCH: Weinheim, 1999. (b) Doyle, M. P.; McKervey, M. A.; Ye, T. Modern Catalytic Methods for Organic Synthesis with Diazo Conpoumds; Wiley-Interscience: New York, 1998. (c) Fursiner, A. Angew. Chem. Int. Ed. 2000, 39, 3012, (d) Trnka, T. M.; Grubbs, R. H. Acc, Chem. Res. 2001, 34, 18. (e) Schrock, R. R.; Hoveyda, A. H. Angew. Chem. Int. Ed. 2003, 42, 4592, (f) Metal Carbenes in Organic Synthesis; Dotz. K. H., Ed.; Topics in Organometallic Chemistry; Vol. 13; Springer-Verlag: Berlin, 2004. (g) Herondon. J. W. Coord. Chem. Rev. 2007, 251, 1158.

2. For reviews on transition metal-catalyzed reactions via carbene, vinylidene, and allenylidene inlermediales generaled from alkynes, see: (a) Ohe, K.; Miki, K.; Uemura, S. J. Synth, Ong. Chem. Jpn. 2004, 62, 978. (b) Miki, K.; Uemura, S.; Ohe, K. Chem. Lett. 2005, 34, 1068 .

3. For other guides to the literature of this research field, see: (a) Fursiner, A.; Davies, P. W. Angew: Chem. Int. Ed. 2007, 46, 3410. (b) Marion, N.; Nolan, S. P. Angew, Chem. Int. Ed. 2007, 46, 2750. (c) Gorin, D. J.; Tosle, F. D. Nature 2007, 446, 395. (d) Bruneau, C.; Dixneuf, P. H. Angew: Chem. Int. Ed. 2006, 45 , 2176.

4. For reviews, see: (a) Zhang, W.; Moore, J. S. Adr. Simh. Catal. 2007, 349, 93. (b) Diver, S. T,; Giessert, A. J. Chem, Rev, 2004, 104, 1317. (c) Grubbs, R. H.; Trnka, T. M.; Sanford, M. S. Cmr. Meth. Inorg. Chen. 2003, 3, 187. (d) Poulsen, C. S.; Madsen, R. Sythesis 2003, 1 .

5. For selected papers on catalytic cycloisomerization of enynes via cyclopropylcarbene complexes, see: (a) Trosi, B. M.; Tanoury, G. J. J. Am. Chem. Soc, 1988, 110, 1636, (b) Trost, B. M.; Hashmi, A. S. K. J. Am, Chem, Soc, 1994, I16, 2183. (c) Chatani, N.; Morimoto, T.; Muto, T.; Murai, S. J. Ani. Chent. Soc. 1994, 116. 6049. (d) Chatani, N.; Kataoka, K.; Murai, S.; Furukawa, N.; Seki, Y. J. Am. Chem. Soc 1998, $l 20,9104$. (e) Chatani, N.; Inoue, H.; Morimolo, T.; Muto, T.; Murai, S. J. Org. Chem. 2001, 66, 4433. (I) Oi, S.; Tsukamoto, I.; Miyano, S.; Inoue, Y. Organometallics 2001. 20, 3704. (g) Pastine, S. J.; Youn, S. W.; Sames, D. Tetrahedron 2003, 59, 8859, (h) Lloyd-Jones, G. C. Ong. Bionol. Chem. 2003, $f, 2$ 15. (i) Yamamoto, Y.; Kuwabara, S.; Ando, Y.; Nagata. H.; Nishiyama. H.; Itoh, K. J. Org. Chem. 2004, 60,6697.

6. For selected papers on catalytic cycloisomerization of $\alpha, a-$-enynes via cyclopropylcarbene or vinylcarbene complex, see: (a) MartinMatule, B.; Nevado, C.; Cardenas, D. J.; Echavarren, A. M. J. Am. Chem, Soc, 2003, 125, 5757, (b) Nielo-Oberhuber, C.; Munoz, M. P.; Buñuel, E.; Nevado, C:; Cardenas, D. J.; Echavarren, A. M. Angew. Chem., Int. Ed. 2004, 43, 2402. (c) Fürstner, A.; Hannen. P. Chem. Commun. 2004, 2546. (d) Mamane, V.; Gress, T.; Krause, H.; Furstner, A. J. Am. Chem. Soc, 2004, 126, 8654. (e) Harrak, Y,; Blaszykowski, C.; Bemard, M.; Cariou, K.; Mainetti, E.; Mouries, V.; Dhimante, A.-L.; Fensterbank, L.; Malacria, M. J. Ani. Chen. Soc. 2004, 126,8656 . (f) Blaszykowski, C.; Harrak, 
Y.; Goncalves, M.-H.; Cloarec, J.-M.; Dhimane, A.-L.; Fensterbank, L.; Malacria, M. Org. Lett. 2004, 6, 3771. (g) Anjum, S.; MarcoContelles, J. Tetrahedron 2005, 61, 4793. (h) Marion, N.; de Frémont, P.; Lemière, G.; Stevens, E. D.; Fensterbank, L.; Malacria, M.; Nolan, S. P. Chem. Conmun. 2006, 2048. (i) Marco-Contelles, J.; Arroyo, N.; Anjum, S.; Mainetti, E.; Marion, N.; Cariou, K.; Lemière, G.; Mouriès, V.; Fensterbank, L.; Malacria, M. Eur. J. Org. Chem. 2006, 46I8. (i) Jiménez-Núñez, E.; Claverie, C. K.; Nieto-Oberhuber, C.; Echavarren, A. M. Angew. Chem. Int. Ed. 2006, 45, 5452, and references therein.

7. Yamamolo, Y.; Kinpara, K.; Saigoku, T.; Takagishi, H.; Okuda, S.; Nishiyama, H.; Itoh, K. J. Am. Chem. Soc. 2005, 127, 605, and references therein.

8. (a) Asao, N.; Aikawa, H.; Yamamoto, Y. J. Ant. Chent. Soc. 2004, 126, 7458. (b) Kusama, H.; Funami, H.; Shido, M.; Hara, Y.; Takaya, J.; Iwasawa, N. J. Am. Chem. Soc. 2005, 127, 2709. (c) Kusama, H.; Iwasawa, N. Chem, Lett, 2006, 35, 1082, and references therein.

9. (a) Kimball, D. B.; Weakley, T. J. R.; Herges, R.; Haley, M. M. J. An. Chem. Soc. 2002, 124, 13463. (b) Shirtcliff, L. D.; Weakley, T. J. R.; Haley, M. M. J. Org. Chem. 2004, 69, 6979.

10. (a) Ohe, K.; Kojima, M.; Yonehara, K.; Uemura, S. Angew. Chem., Int. Ed. Engl. 1996, 35, 1823. (b) Manabe, T.; Yanagi, S.i.; Ohe, K.; Uemura, \$. Organometallics 1998, 17, 2942. For ruthenium-promoted similar reaction, see: (c) Wang, Y.; Finn, M. G. J. An. Chem. Soc. 1995, 117,8045,

11. Ohe, K.; Miki, K.; Yokoi, T.; Nishino, F.; Uemura, S. Organometallics $2000,19,5525$.

12. (a) Miki, K.; Yokoi, T.; Nishino, F,; Ohe, K.; Uemura, \$. J. Organomet, Chem, 2002, 645, 228, (b) For isobenzofurylcarbente complexes, see: Casey, C. P; Stroman, N. A.; Guzei, I. A. Organtonetallics 2004, 23,4121.

13. Ohe, K.; Yokoi, T.; Miki, K.; Nishino, F.; Uemura, S. J. Ant. Chem. Soc. 2002, 124,526.

14. (a) Miki, K.; Nishino, F.; Ohe, K.; Uemura, S. J. Am. Chem. Soc. 2002, 124, 5260. (b) Miki, K.; Yokoi, T,; Nishino, F.; Kato, Y,; Washitake, Y.; Ohe, K.; Uemura, S. J. Org. Chem. 2004, 69, 1557.

15. Nishino, F.; Miki, K.; Kato, Y.; Ohe, K.; Uemura, S. Org. Leff. $\mathbf{2 0 0 3}, 5,2615$.

16. Kato, Y.; Miki, K.; Nishino, F.; Ohe, K.; Uemura, S. Org. Left. $2003,5,2619$.

17. (a) Miki, K.; Washitake, Y; Ohe, K.; Uemura, S. Angew. Chem. Int. Ed. $2004,43,1857$. For transition metal-catalyzed ole fination of aldehydes using diazoalkanes and phosphines, see: (b) Cheng, G; Mirafzal, G. A.; Woo, L. K. Organonetallics 2003, 22, 1468 , and references therein. (c) Aggarwal, V. K.; Fulton, J. R.; Sheldon, C. G.; de Vicente, J. J. Am. Chem. Soc. 2003, 125, 6034.

18. (a) Rautenstrauch, V. Tetrahedron Lett. 1984, 25, 3845. (b) Rautenstrauch, V. J. Org. Chem. 1984, 49, 950. For palladiumcatalyzed oxidative rearrangement of propargylic esters, see: (c) Kataoka, H.; Watanabe, K.; Goto, K. Tetrahedron Lett. 1990, 3/, 4181 .

19. (a) Bowden, B.; Cookson, R. C.; Davies, H. J. Chent. Soc., Perkin Trans. I 1973, 2634. (b) Cookson, R. C.; Cramp, M. C.; Parsons, P. J. J. Chem. Soc., Chem. Commun. $1980,197$.

20. For recent advances in isomerization of propargyl esters into allenyl esters, see: (a) Stomerk, A. W.; Kel'in, A. V.; Gevorgyan, V. Angew. Chent. Int. Ed. 2004, 43, 2280. (b) Cariou, K.; Mainetti, E.; Fensterbank, L.; Malacria, M. Tetrahedron 2004, 60, 9745. (c) Zhang L. J. Am. Chem. Soc. 2005, 127, 16804. (d) Zhang, L.; Wang S. J. Am. Chem. Soc. 2006, 128, 1442. (e) Zhao, J.; Hughes, C. O.; Toste, F. D. J. Am. Chem. Soc. 2006, 128, 7436. (f) Oh, C. H.; Kim, A.; Park, W.; Park, D. I.; Kim, N. Synlet 2006, 2781. (g) Wang, S.; Zhang. L. J. Ani. Chem. Soc. 2006, 128, 8414. (h) Wang, S.; Zhang, L. Org. Lett, 2006, 8,4585 . (i) Marion, N.;
Diez-González, S.; de Frémont, P; Noble, A. R,; Nolann, S. P. Angew. Chem. Int. Ed. 2006, 45, 3647. (j) Buzas, A.; Gagosz, F. $J$. Ant. Chent. Soc. 2006, $128,12614$.

21. Mainetti, E.; Mouriès, V.; Fensterbank, L.; Malacria, M.; MarcoContelles, J. Angew: Chem. Int. Ed. 2002, 41,2132.

22. Most recent papers render a planar vinylcarbene complex as the actual intermediate improbable. See: (a) Soriano, E.; Ballesteros, P.; Marco-Contelles, J. Organontetallics 2005, 24, 3172. (b) Fürstner, A.; Hannen, P. Chent. Eur. J. 2006, I2,3006. (c) Soriano, E.; Marco-Contelles, J. J. Org. Chem. 2007, 72, 1443.

23. (a) Miki, K.; Ohe, K.; Uemura, S. Tetrahedron Lett, 2003, 44, 2019. (b) Miki, K., Ohe, K.; Uemura, \$. J. Org. Chem. 2003, 68, 8505. (c) For Au-catalyzed stereoselective cyclopropanation, see: Johansson, M. J.; Gorin, D. J.; Staben, S. T.; Toste, F. D. J. An. Chem. Soc. 2005, 127, 18002 .

24. Nakanishi, Y.; Miki, K.; Ohe, K. Tetrahedron 2007, 63, 12138.

25. For P1- or Au-catalyzed similar pentannulation reactions, see: (a) Shi, X.; Gorin, D. J.; Toste, F. D. J. Am. Chem. Soc. 2005, 127, 5802. (b) Prasad, B. A. B.; Yoshimoto, F. K.; Sarpong, R. J. Am. Chem. Soc. 2005, 127, 12468. (c) Faza, O. N.; López, C. S.; Álvarez, R.; de Lera, A. R. J. Am. Chem. Soc. 2006, 128, 2434. (d) Pujanauski, B. G.; Prasad, B. A. B.; Sarpong, R. J. Am. Chem. Soc. 2006, 128, 6786. (e) Peng, L.; Zhang, X.; Zhang, S.; Wang, J. J. Org. Chem, 2007, 72, 1192. (I) Smith, C. R.; Bunnelle, E. M. Rhodes, A. J.; Sarpong, R. Org. Lett. 2007, 9, I169.

26. Miki, K.; Fujita, M.; Uemura, S.; Ohe, K. Org. Lett. 2006, 8, 1741.

27. Ikeda, Y.; Murai, M.; Abo, T.; Miki, K.; Ohe, K. Tetrahedron Lett. $2007,48,665 \mathrm{I}$.

28. Ohe, K.; Fujita, M.; Matsumoto, H,; Tai, Y,; Miki, K. J. Am. Chem, Soc. 2006, 128, 9270 .

29. (a) DePinto, J. T,; McMahon, R. J. J. Am. Chem. Soc. 1993, 115, 12573. (b) Naro, T.; Masuda, T.; Ichimura, A. S.; Koga, N.; Iwamura, H. J. Ant. Chem. Soc. 1994, 116,6179 . (c) Bowling, N. P.; Halter, R. J.; Hodges, J. A.; Seburg, R. A.; Thomas, P. S.; Simmons, C. S.; Stanton, J. F.; McMahon, R. J. J. Am. Chem. Soc. 2006, 128, 329l. (d) Bowling, N. P.; McMahon, R. J. J. Org. Chem. 2006, 71,5841.

30. (a) Takeda, T.; Ozaki, M.; Kuroi, S.; Tsubouchi, A. J. Org. Chen. 2005, 70, 4233. (b) Barluenga, J.; de la Rúa, R. B.; de Sáa, D.; Ballesteros, A.; Tomás, M. Angew. Chem. Int. Ed. 2005, 44, 4981. (c) Barluenga, J.; Garcia-Garcia, P; de Sáa, D.; FernándezRodríguez, M. A.; de la Rúa, R. B.; Ballesteros, A.; Aguilar, E.; Tomás, M, Angew. Chem, Int. Ed. 2007, 46, 2610.

31. A $[1,1.5]$ shift for $\mathrm{Re}$ and $\mathrm{Mn}$ carbene complexes was defined as different metallotropic shifts. See: [Re]; (a) Casey, C. P.; Dzwiniel, T. L.; Kraft. S.; Guzei, I. A. Organometallics 2003, 22, 3915. (b) Casey, C. P.; Dzwiniel, T. L. Organometallics 2003, 22, 5285. (c) Ortin, Y; Sournia-Saquet, A.; Lugan, N.; Mathieu, R. Chem. Commin, 2003, 1060. [Mn]; (d) Casey, C. P.; Kraf, S.; Powell, D. R. J. An. Chem. Soc. 2000, 122, 3771. (e) Casey, C. P.; Kraft, S.; Powell, D. R. Organometallics 2001, 20,265I. (f) Casey, C. P.; Kraft, S.; Kavana, M. Organometallics 2001, 20,3795. (g) Casey, C. P.; Kraf, S.; Powell, D. R. J. Am. Chem. Soc. 2002, 124, 2584.

32. For precedents of the catalylic metallotropic shif, see: (a) Padwa, A.; Austin, D. J.; Gareau, Y.; Kassir, J. M.; Xu, S. L. J. Am. Chem. Soc. 1993, 115, 2637. (b) Kim, K.; Miller, R. L.; Lee, D. J. An. Chem. Soc. 2005, 127,12818 . (c) Kim. K.; Lee, D. J. Am. Chen. Soc. 2005, 127, 18024. (d) van Ottero, W. A. L.; Noidi, E. L.; de Koning, C. B.; Fernandes, M. A. Tetrahedron Lett. 2004, 45, 659.

33. For recent advances in calalytic metallotropic shifl, see: (a) Cho, E. J.; Kim, M.; Lee, D. Eur. J. Org. Chem, 2006, 3074. (b) Gorin, D. J.; Dubé, P.; Toste, F. D. J. Ant. Chem. Soc. 2006, $128,14480$. (c) Cho, E. J.; Kim, M.; Lee, D. Org. Left. 2006, 8, 5413. (d) López, S.; Herreo-Gomez, E.; Pérez-Galán, P.; Nieto-Oberhuber, C.: Echavarten, A. M. Angew. Chem. Int. Ed. 2006, 45, 6029. 